\title{
One message on the state of science
}

\section{The new Presidential Science Advisor last week gave the House of Representatives a vision of how smaller budgets may bring strength. He was partly disingenuous; may he also be right?}

The United States Congress has a built-in flair for the theatrical. So much is clear from the circumstances that brought Dr George Keyworth and Dr Frank Press (his predecessor as Presidential Science Advisor now transmogrified to president of the National Academy of Sciences) to the same witness table last week (see page 601). True to expectation and perhaps even to form, Dr Keyworth, the government representative, talked confidently of how his government's policies would make the United States research enterprise more and not less efficient. Dr Press, a little on the defensive, of fered a compact between the research community and the United States Administration that would assure basic research in the United States of modestly rising budgets and the United States government of the cooperation of the research community in transferring funds from the "less productive areas or institutes". Both witnesses were talking about the future, naturally enough. Neither of the set speeches mentioned the 12 per cent cut in federal budgets which President Reagan declared in August but which Congress will probably, in the end, decline to give him. But Dr Keyworth's vision was of a future so distant that, by the time it arrives, he may again be an ordinary person not bound to support the policies of the administration of the day.

Whatever the time scale of their dreams, however, Keyworth and Press agreed last week on one essential point - that the federal government has a continuing responsibility for the support of basic research. Keyworth argued that the private sector cannot be expected to support a sufficient effort in basic research, given its short-term need for profit; Press tended to quote President Lyndon Johnson on the subject. One obvious difficulty, which each of them might have mentioned, is that Congress is unlikely to endorse such a fine distinction between basic research - the pursuit of generally unpopular academics and what is called applied research and demonstration. Why should a congressman, never more than two years from his reelection ordeal, vote for the general distribution of research funds to the generality of academics when he could vote instead for his own state's favourite federal laboratory or demonstration project? Dr Keyworth should have been prepared to remind Congress of its own responsibilities. Dr Press would no doubt have been prepared to back him up with accounts, gathered at first hand, of how the pork barrel rolls.

For the immediate future, the outstanding question is whether the scientific community is in a position to do what Dr Keyworth asks of it, and to use the system of peer-review committees, and of the advisory committees that advise the grant-making and mission-oriented agencies respectively, in such a way as to concentrate funds for basic research in fields of enquiry and on institutions that are likely to make best use of them. Broadly speaking, the answer is that it all depends. For Press is also right to imply in what he said last week that the research community can do this kind of job when it believes that it can do so safely, knowing that its paymasters will not take its recommendations of places or people from which funds can be withheld as licences to go ahead while saying that recommendations of where support should be increased can wait until the economy has improved. Dr Keyworth's speech last week, full though it was of references to a creative basic research community $x$ years from now, conspicuously lacked a sense of responsibility towards - or even regret for - those who have contributed to the same endeavour in the past $x$ years. Keyworth was looking not at the future but at the horizon beyond it.

Press's recipe for the immediate future is, unfortunately, equally unpalatable. Faced with present economic uncertainties, the United States government could not agree to a compact that would assure basic research of some specified rate of growth each year. The economic crisis that afflicts science in the United States (and elsewhere) has arisen precisely because people are uncertain about the economic future. Other institutions are similarly afflicted. None can be insulated. Keyworth last week would have been wrong to promise that they might be. The best course for him and Dr Press for the weeks ahead will be to make plain that nobody is owed a living, but that the government will do what it can, within the resources at its disposal, to make the best use of what can be spent on basic research.

Two minor scandals stand out from last week's exchange. Dr Keyworth argued in his statement that things may not be too bad because the Pentagon's spending on basic research will be increasing in the years ahead. One trouble is that what the Department of Defense counts as basic research is not always what other people understand by the term. Another is that the Pentagon's sense of what is excellent is often compromised by its sense of what may be expedient. If the traditional and trusted sources of support for basic research are to be cut back but the Pentagon enlarged and the research community as a result given less of a say in what is excellent and worthwhile, should not $\mathrm{Dr}$ Keyworth have been urging that this year's increase in the Pentagon's operating budget should be matched by a corresponding increase of the budgets of the agencies dedicated to (and skilled at) providing support for basic research?

The second scandal that will stick in people's minds is Dr Keyworth's homily last week about the neglect of science and mathematics in American high schools. Since the post-sputnik era in the late 1950s, enthusiasm for the physical sciences has evidently waned. Rightly, Dr Keyworth shares with other observers a sense of anxiety about the consequences. Will United States universities in future be providing remedial mathematics as freely as they now have to of fer remedial English? Or will it simply be that the brightest young people follow different kinds of courses, letting American industry depend on skilled people recruited from abroad? The fears may be exaggerated, but $\mathrm{Dr}$ Keyworth's defence of his government's inaction is equally an exaggeration of the doctrine that Republican governments are ideologically opposed to intervention in other people's affairs. Keyworth said that the Administration is concerned at the decline in high school studies in the physical sciences, but that education is a matter for state and local government and that he had confidence that, sooner or later, they would see the light. Can he be sure, especially when the government for which he works has decided (as it did in its March budget) that the National Science Foundation should be effectively robbed of funds for the further development of the science curriculum? If the benefits of basic research are too distant to be left to industry, can it safely be assumed that the long-term needs of the educational system can be entrusted to embattled school committees? And if not, does not the Administration have a duty to show the way? The National Science Foundation's educational programme may have aged ungracefully, but the Administration cannot wash its hands of the set of problems its science adviser has identified. 